\title{
9: The (re)-emergence of civil society in areas of state weakness: the case of education in Burma/Myanmar ${ }^{1}$
}

\author{
Jasmin Lorch
}

\section{Introduction}

In September 2007, Burma/Myanmar experienced its largest popular uprising since 1988. The protests, which posed the first serious challenge to the military regime in nearly 20 years, were widely perceived as an outburst of popular frustration about the pervasive failure of the State to provide for the basic welfare of its citizens. From January on, the '88 Generation Students Group ${ }^{2}$ led small-scale demonstrations that focused mainly on economic and social issues. Several signature campaigns tried to motivate people to write to the government describing their everyday problems, including rising food prices and the lack of access to education (Thawnghmung and Myoe 2008; see also the chapters by Horsey and Win Min in this publication ). In the international media, the uprising was often described as the 'Saffron Revolution', because it was led by thousands of young Buddhist monks - a fact that took most Burma/Myanmar experts by surprise. In view of the economic hardships they faced and the multitude of social-welfare functions they performed, the Buddhist monks' leading role in the uprising is not incomprehensible. Most importantly, monastic education has long served as a stopgap function for the failure of the state-run education system. In the years before the uprising, the teaching load of the monks had increased tremendously as fewer and fewer parents could afford to send their children to a state-run school. At the same time, due to growing poverty, many ordinary people could donate less and less to the monks, who rely entirely on alms for their own funding. Shortly before the demonstrations, many monks allegedly could afford no more than one meal a day. As the example of the Sangha 3 suggests, the September uprising can therefore be seen as the outcome of an overstraining of community self-help networks trying to cope with the pervasive failure of the welfare state.

Civil-society development is a relatively new topic in Burma/Myanmar studies, as it has long been assumed that civil society cannot exist fully in such an authoritarian context (see, for example, Steinberg 1999). Contrary to such assumptions, some more recent studies have found that civil society has been (re)-emerging in the past few years (see, for example, Heidel 2006; ICG 2001; 
South 2004). As this author has argued elsewhere, spaces for civil-society actors in authoritarian Burma/Myanmar exist in at least two areas in which the authoritarian state is weak or failing: first, in various sectors of the weak welfare state; and second, in some of the negotiated spaces of relative ethnic autonomy in the cease-fire areas (Lorch 2006, 2007). ${ }^{4}$ Against this backdrop, the (re)-emergence of civil society-based self-help groups in the education sector is part of a larger trend that has been taking place in Burma/Myanmar in recent years: the military regime has started to tolerate welfare provision by civil-society actors in areas of tremendous welfare need that the State is unable or simply unwilling to deal with itself (Lorch 2007). Even though education is highly regarded in Burma/Myanmar, the state-run education system has been deteriorating continuously, in terms of accessibility and quality. In some rural areas, for instance, public schooling is not available at all, either because the government has never constructed a school building in the village or because teachers refuse to go to these remote areas (see also Marie Lall's chapter in this publication). Moreover, teachers and professors often lack basic qualifications, because the state-run teacher-training system has been steadily degrading. As a consequence, civil society-based organisations have begun to provide makeshift solutions to bridge the accessibility gap. At the same time, the commercial private sector has started to move into the quality gap and several private schools catering to the middle class have started operating in recent years (see Lall's chapter in this volume). In contrast with the non-profit-making civil society-based models, however, these schools usually charge quite high fees.

In principle, education should be a priority sector for international engagement, as it is a key to national development (Tin 2004), along with improvements in other important welfare sectors such as health. Moreover, if donors were able to engage with civil-society actors in the education sector, this could be a starting point for gradually changing Burma/Myanmar's authoritarian political culture (see Han Tin in this volume). The continuing engagement of the UN International Children's Emergency Fund (UNICEF) in Burma/Myanmar's education sector provides evidence that the donor community takes the importance of education for development seriously. ${ }^{5}$ The role of the international aid community in the field of education has, however, so far been limited, as the government is highly suspicious of international involvement this sector, which - despite poor resource allocation - it considers an area of national interest. In particular, there is almost no institutionalised cooperation between donors and local civil-society actors in the field of education and information about the state of civil-society activities in this area remains scarce. Against this backdrop, this chapter focuses on an analysis of what spaces are available for civil-society actors in the education sector. $^{6}$ It argues mainly that even though civil-society groups have managed to bridge some of the gaps that exist in the formal education sector, they lack the capacity to provide a substitute for a functioning state-run education system. 
Due to the lack of reliable data, the findings presented here should be regarded as preliminary results intended to inspire further research and discussion.

\section{Civil society in the context of authoritarianism and state weakness: some theoretical reflections}

\section{Civil society under authoritarian rule}

According to normative definitions, the sphere of civil society is characterised by its extensive autonomy from the State and the market, and by voluntary participation, tolerance, discursive procedures of decision making and horizontal networks. Correspondingly, it is assumed to generate trust and democratic values and to consequently promote democracy. ${ }^{7}$ In order to identify and understand civil-society developments in authoritarian Burma/Myanmar, such normatively highly loaded concepts are not very useful. Compared with the theoretical ideal type, Burma/Myanmar's civil society is still embryonic in nature (Lorch 2006). This study therefore relies on a broad, empirical definition of the term:

Civil society refers to the arena of uncoerced collective action around shared interests, purposes and values. In theory, its institutional forms are distinct from those of the state, family and market, though in practice, the boundaries between state, civil society, family and market are often complex, blurred and negotiated. Civil society commonly embraces a diversity of spaces, actors and institutional forms, varying in their degree of formality, autonomy and power. Civil societies are often populated by organisations such as registered charities, development non-governmental organisations, community groups, women's organisations, faith-based organisations, professional associations, trades unions, self-help groups, social movements, business associations, coalitions and advocacy groups. (LSE 2008)

As I have argued previously, civil society generally bears a relation to the state in which it operates. ${ }^{8}$ A strong, democratic, constitutional state is the sine qua non for an autonomous and democratic civil society to flourish. In Burma/Myanmar, however, as one of the longest-enduring military regimes in the world, civil-society organisations usually mirror the 'dark sides' (Lauth 2003) of the authoritarian state in which they operate, such as hierarchies, exclusiveness and patterns of cooption. In order to be able to run their self-help programs, civil-society actors in authoritarian states frequently have to maintain functional ties with members of the ruling establishment - or even let themselves become partially coopted by the latter (Perinova 2005). Moreover, vertically structured relationships or religious and ethnic cleavages in society as a whole are usually found in civil society as well (Croissant 2000; Howell 1999). This general finding is especially relevant for religiously and ethnically segmented states such as Burma/Myanmar. 


\section{Spaces for civil society in areas of state weakness}

Weak states are states that fail to deliver positive political goods - such as security, health, education, a reliable legal framework and functioning infrastructure - to their people (Rotberg 2002). Schneckener (2006) has attributed three core service-delivery functions to the State: first, the function of territorial control and the provision of public security; second, the function of welfare provision; and third, the function to establish a democratic constitutional state and a reliable legal system. In the service delivery view, strong authoritarian regime features and state weakness are not mutually exclusive (Schneckener 2004). As Rotberg (2004:5) puts it, 'There is a special category of the weak state...That is the seemingly strong case, always an autocracy, that rigidly controls dissent...but at the same time provides very few political goods.' Burma/Myanmar certainly falls under this category. ${ }^{9}$

More recent studies on the phenomenon of state weakness have shown that if the State fails to perform one of its core service-delivery functions, other actors can move into the gaps that exist. While Rotberg (2004) refers especially to warlords and other criminal non-state actors, Risse (2005) also identifies economic actors, non-governmental organisations (NGOs), family clans and other local groups that practise alternative forms of governance in areas of state weakness. Some of these groups account for civil-society actors in line with the definition that forms the theoretical basis of this chapter. As civil-society theories and the research on weak states have so far remained largely unrelated, theory does not tell us how precisely civil society constitutes itself in the context of state weakness. Ottaway (2004), however, has made the interesting point that in weak states 'modern civil society', which usually comprises secularised and formally organised groups such as NGOs, tends to be rather weak. At the same time, 'traditional civil society', which comprises mostly informal groups such as religious and ethnic organisations, can be quite strong as it provides coping mechanisms for state failure such as alternative, community-based schooling.

The State of Burma/Myanmar can be considered particularly weak with regard to the core function of providing for the welfare of its population. The failure of the state-run education system constitutes but a subcategory of this general failure of the welfare state. Furthermore, certain ethnic minority areas are not under the direct control of the central state, which limits its territorial power monopoly. Since 1989, the regime has concluded cease-fires with most of the armed ethnic resistance groups, thereby granting them some degree of autonomy. As a result, some room for manoeuvre exists for civil-society actors in the welfare-provision sector and in certain territories with a degree of ethnic autonomy. 


\section{The weakness of the state-run education system}

Government expenditure on education is estimated to amount to only about 1 per cent of gross domestic product (GDP) (DFID 2008). In many rural areas, the government education system is non-existent. This includes frequent cases in which there is a school building but no teacher working in the village. Teachers are usually reluctant to go to the rural areas, particularly as they receive no adequate salaries to compensate them for this. If teachers are forcibly transferred to remote villages, they often do not stay there. As a consequence, rural schools in particular are mostly overcrowded and the student/teacher ratio is very high. Furthermore, schools are mostly poorly equipped and usually lack basic teaching materials such as benches, tables and textbooks. Moreover, schoolbooks and curricula tend to be outdated.

Teachers are mostly poorly trained and teaching methods tend to be repetitive, outdated, teacher centred and based on ex cathedra teaching. The state-run teacher-training system has been steadily deteriorating. Even the Ministry of Education (MOE 2006) itself admits that not all teachers have an academic qualification or have even 'attended certified courses'. Apart from the problems mentioned, there is also an obvious lack of vocational skills training as well as a dearth of capacity building in fields such as management, project-oriented work and even English, which international organisations and businessmen active in Burma/Myanmar recognise instantly as soon as they try to hire local staff. What is particularly worrying in this regard is that, according to several international aid workers, the education level is usually lower the younger the applicants are, which indicates a continuing erosion of the education system.

This erosion is characterised not only by a lack of access to, and the quality of, education, but by 'a system that suppresses critical thinking and...discourages creativity'. As a consequence, there is meanwhile, a 'pervasive cynicism about the process of education'. ${ }^{10}$ In many instances, people seem to have given up on the State. As a consequence, several non-profit and self-help approaches to the provision of basic education, as well as professional and life skills, have (re)-emerged. In this regard, it is interesting that during a rare civil-society workshop conducted in Burma/Myanmar, most of the participants from civil society defined their opportunities in terms of unmet community needs for services - that is, in terms of gaps. ${ }^{11}$ The current Myanmar local NGO directory (DLN 2005), which lists only registered organisations with an office in Yangon, mentions 57 NGOs, including monastic schools and church-based and Islamic organisations that engage in education. As many civil-society initiatives in Burma/Myanmar are informal in character and operate on a local level, the real number of self-help groups in the education sector can comfortably be estimated to be much higher. 


\section{Civil society-based education systems in government-controlled areas}

\section{Buddhist monastic education}

Before British colonial rule, Buddhist monasteries were the main education institutions in Burma/Myanmar. Until today, monastic schools, or monastic education centres as they are often called, have been the most important civil-society institutions bridging the accessibility gap in the state-run education system in government-controlled areas. While public schooling is not available in many rural regions, there is a monastery in nearly every village (UNESCO 2002). Monastic schools cater particularly to poor children, are free of charges such as enrolment fees and usually provide teaching materials such as books for free. Moreover, many monasteries serve as schools and orphanages at the same time.

Traditionally, monastic education is characterised by non-formal and lifelong learning. In this sense, it can be said to represent the unity of life and religion, which still exists in many rural regions of Buddhist Burma/Myanmar. In its pure and traditional form, monastic education can thus be considered fundamentally different from the formal secular education system, which considers education as a preparation for life rather than a form of life itself (Tin 2004). In British colonial times, the fight for the right to a distinctively Buddhist education-as opposed to the secular education system imposed by the British - constituted a significant part of the anti-colonial struggle (Zoellner 2007a). Contrary to pre-colonial times, however, in present-day Burma/Myanmar, a secular national education system exists, but fails to provide adequate services. In this context, monastic schools often provide not only parallel but complementary education models, and the line between informal religious and formal secular education has become blurred to some extent. Besides non-formal and religious education, a growing number of monastic schools have started to also teach children basic skills needed for secular life; some of them have meanwhile even become (partly) incorporated into the formal education system.

Today, three main categories of monastic schools can be seen: the first confines itself to imparting Buddhist teachings; the second is made up of monastic schools that consider it their main task to impart Buddhist teachings but which, at the same time, also teach children basic literacy skills (although these second-category monastic schools are unable to hold exams or to award their pupils certificates that are recognised by the government); the third are those that adopt the government curriculum, which means that they engage in formal education. According to official government figures, 1183 of these third-category monastic schools are recognised by the government in a kind of coeducation system. They seem to be registered with the MOE and the Ministry of Religious Affairs (MRA). According to the same source, these 1183 schools reached 158040 pupils in the 
2003-04 academic year (MOE 2006). If monastic schools are recognised by the government, their pupils also have the possibility of acquiring an officially recognised degree. They can do their final exams either at a government school or at their respective monastic school, which then, however, has to send the exams to the ministry responsible for marking and issuing the certificates. ${ }^{12}$ For officially recognised monastic schools, a kind of bridging system makes it possible for pupils to change from monastic to government schools. If, for example, pupils complete the primary level at an officially recognised monastic school, they are sometimes allowed to do a special test. If they pass this test, they can gain acceptance to a government middle school. According to other official statistics obtained from a UN agency active in the country and which are largely consistent with the official source (MOE 2006) cited above, the majority of all officially recognised monastic schools teach at the primary or post-primary levels. Some, but much fewer, teach at the middle level. ${ }^{13}$ Furthermore, two to five officially recognised monastic schools were reported to teach at the high-school level. ${ }^{14}$ Moreover, various monastic education centres also engage in vocational skills training such as computer training activities. The figures cited here are likely to be incomplete due to the lack of reliable data, but they point to a remarkable tend: by providing secular education and professional skills to poor children, some Buddhist monks seem to deliberately try to bridge the accessibility gap that exists in the state-run education system.

It should also be noted, however, that in terms of quality, monastic schools tend to show the same deficits as the state-run education system. For instance, learning is mostly by rote even though there are some important exceptions. Most monastic schools teach novices and lay children together and provide their educational services regardless of race and religion. Moreover, monasteries sometimes serve as protective umbrellas for more secular educational initiatives run by lay professional teachers or other lay volunteers (who may or may not have been trained). There are, however, also monastic schools whose main purpose is to counter similar efforts by the Christian churches and to prevent people converting from Buddhism to Christianity. This pattern is especially relevant with regard to those monastic schools that are also orphanages. Even though not all of the children they care for are Buddhist, some monastic orphanages require every child who wants to live in their compound to wear a Buddhist novice's robe. Even in orphanages where this is not the case, Christian or Muslim children are sometimes encouraged to convert to Buddhism. Asked about the religion of his students, one monastic schoolteacher said that after living in the monastery for a while the boys normally became Buddhist. Another more critical dimension of monastic education relates to gender. Monastic schools cater mainly to boys (UNESCO 2002), especially those that, at the same time, serve as orphanages. ${ }^{15}$ The author also visited some monastic orphanages that were run by Buddhist nuns and catered to girls, but these did not provide secular 
education such as literacy and numeracy. Moreover, most of them faced even more economic hardship than those monastic orphanages visited that catered to boys.

Monastic education centres vary in size and in the degree to which they are coopted by the regime. While some have only a few dozen pupils, others have between 100 and 800 (some big monastic schools have even more pupils, but they are exceptions to the rule). As a basic principle, the bigger an institution is, the more coopted by the State it tends to be. Small and rural monastic schools often centre on one individual monk and are more or less independent from government interference. Their capacities, however, are also often limited and their teaching materials quite basic (South 2004). In constrast, large monastic schools often have quite reasonable facilities and offer a number of secular subjects, sometimes even including foreign languages, particularly English. Some of the big monastic education centres visited could even afford to hire university students or professional teachers to give courses and had their own professional skills training centres or income-generating facilities such as tailor or carpenter shops. Such relatively large-scale functions come, however, mostly with a certain degree of cooption. For example, a general pattern seems to be that government officials pay public visits to the monastery and give (largely symbolic) donations in order to take some of the credit for themselves. Another aspect of cooption is that many of the monks who run big monastic schools have received their own education at the state-run Theravada Buddhist University, which operates under the MRA and which the government considers a tool to promote but also to 'purify' and control the Buddhist faith.

According to one expert on Buddhism in Burma/Myanmar, ${ }^{16}$ the young monks who led the 2007 uprising came predominantly from the private monk schools, a specific type of monastery. Monk schools are purely religious education institutions, which cater to adult monks and impart Buddhist teachings on a tertiary - that is, college or university - educational level. They thus constitute a subtype of the first category of monastic schools depicted above. State-run and private monk schools exist, and the young monks who played a leading role in the 2007 demonstrations came predominantly from the latter. Nevertheless, by protesting against the government's welfare policies and the fuel-price hike, these young monks certainly expressed the socioeconomic and political grievances of the whole Sangha and the population at large. (According to the same source, the demonstrations were so well organised because monks who belonged to the same monk school usually marched together in one block. Different monk schools could, in turn, coordinate their actions because young monks from different monk schools knew each other from their home villages and, before the demonstrations, called each other up.) In the aftermath of the uprising, the private monk schools have faced a harsh government crackdown and many of them have been abandoned or closed down. 
Monastic schools, including orphanages, that cater to children are run mostly by a single monk or sometimes by a few (two to five) monks; they usually teach a certain number of young novices and an often larger number of lay children together. (In contrast, the monk schools usually host a fairly large number of already ordained monks.) To the author's limited knowledge, these monastic schools did not play a role in the 2007 uprising. Nevertheless, as some academics and a local aid consultant from within Burma/Myanmar suggested, some of them might have been affected by the subsequent government crackdown. This is particularly likely for monastic orphanages that cater to older boys and that resemble the monk schools in their organisational structures and beneficiaries, especially as they often require all boys in their compound to wear a Buddhist novice's robe.

So far, the role of the international donor community in promoting monastic education has been limited at best. While some monastic schools do receive funds and donations from international friends, such as travellers or small foreign NGOs, this happens largely on an individual basis. Except for a few notable exceptions, the cooperation is usually not institutionalised. The fact that hardly any Burma/Myanmar observers foresaw the 2007 uprising of the monks provides evidence that there is still a huge lack of information about the Buddhist monasteries and monastic schools and that further research is needed in order to assess their overall social and political impact.

\section{Extra tuition, early childhood development, professional skills training and capacity building: the role of NGOs, community-based organisations and individuals}

Commercial as well as non-profit 'learning centres' that provide extra tuition have become a common part of the urban landscape. A number of local NGOs and engaged individuals, often university students, run free or low-cost extra tuition programs in order to help children who have problems at government schools but are unable to pay for extra tuition. Many of these programs focus on English or help students prepare for their matriculation examination. While free or low-cost extra tuition often constitutes a valuable support for poor children, it should be noted that it can also be counterproductive. The quality of these programs is often quite inadequate and the volunteers who give lessons are often insufficiently qualified and have usually not been trained as teachers. As in the public schools, learning is mostly by rote. Moreover, classes tend to be large (up to 100 students) and quite often students from different grades - ranging from primary to high-school level - are taught together. What is more, with the state-run education system deteriorating, it has become common practice for parents to have their children take extra tuition. As a result, some 10-year-old children interviewed spent almost all of their day in class, going to the government school in the morning, to extra tuition with costs in the afternoon 
and to another, free extra tuition in the evening - sometimes as late as nine or ten o' clock. With the absorptive capacity of a 10-year-old child unquestionably limited and the quality of the tuition often inadequate, the educational impact of some of these programs becomes questionable. It is also noteworthy that in many instances of extra tuition, the line between civil society, the State and corruption has become blurred. As teachers usually cannot live on their meagre salaries, many have resorted to extra tuition as a way to supplement their income. Some of these extra-tuition programs run by professional teachers operate at low cost and might constitute a valuable complement to regular tuition where classes are usually too big for teachers to be able to respond to individual students. In some problematic cases, however, teachers have stopped teaching the subject matters most relevant for passing the final exams in regular class and have transferred these teaching units to the extra-tuition courses instead. Some teachers even provide the notes, or handouts, on which the exams are based through paid tuition classes only. ${ }^{17}$

Limited space also exists for community-based and NGO activities in the early childhood development (ECD) sector, which is aimed at children up to five. At the village level, these initiatives are often informal and conducted by local community leaders. Some of the registered local NGOs run more formally organised nursery or pre-primary schools, which operate on a larger scale. According to an NGO worker, pre-primary schoolteachers usually try to stimulate creative thinking in children, play and sing songs with them and start to teach them the Burmese/Myanmar and the English alphabets. Some foreign as well as local church-based NGOs also focus on capacity building for local, unregistered community-based organisations that already have their own ECD programs in place but lack knowledge in child-centred teaching methods. The fact that several international NGOs have also managed to engage in ECD indicates that this sector is generally a bit more open than the education sector as a whole. Interestingly, it is the Ministry of Social Welfare (MSW) and not the MOE that is in charge of ECD. This seems to provide a small window of opportunity for enhanced civil-society engagement. As a local staff member of an international NGO active in ECD stressed, on an individual level, cooperation between NGO members and MSW officials sometimes worked quite well. What is still lacking, however, is a bridging system between non-state ECD programs and the state-run primary school system. According to a local employee of an international NGO that works in the ECD sector, once children transfer from an ECD program into the rigid state-run education system, they are often confused by the contrast in approach.

Another field of local NGO engagement is vocational-skills training. The 'Myanmar Professional Skills Training Association' in Yangon, ${ }^{18}$ for example, offers courses in different fields including nursing, gardening and financial accounting. It also has a few computers and offers training that focuses on basic office skills. Most of the courses charge a small attendance fee and are thus 
unlikely to reach the hard-core poor. This NGO, however-like others in this field-faces financial constraints itself. The computer classes, for instance, are often interrupted by electricity cuts as the organisation cannot afford a generator. Moreover, this association usually relies on the voluntary engagement of its teachers and trainers, who are often local pensioners.

Some unregistered community-based organisations have also set up 'training centres' that offer post-high school education and target ill-educated school leavers. Teachers, ex-teachers or non-professional volunteers from the local community often conduct courses. Some of these training centres have received financial support and capacity building from international NGOs. Nevertheless, in most cases, teacher training is still a major need. ${ }^{19}$ As a rule, NGO vocational training programs cannot provide students with an officially recognised degree. Some NGOs, however, maintain contacts with local enterprises and also help their graduates by writing recommendation letters to possible future employers. As the government is wary of all initiatives that might contribute to empowerment, a number of local NGOs do not engage in education directly, but have opted instead to engage in less controversial education support activities. Some give grants to poor parents whose children are enrolled in government schools. Others have established free hostels for poor children or young adults who leave their remote rural areas in order to seek education and training in the cities.

Local NGOs and community-based organisations also make important contributions in the field of capacity building for development-oriented work. This includes training activities in project management, proposal writing, financial accounting, community organising, leadership skills, conflict management and English. Basically, these programs target three different groups of people: first, (future) staff members of local NGOs; second, local community leaders such as pastors, village elders or socially engaged local businessmen who can later pass their skills on to their respective local communities - or potentially even establish their own informal skills-training centres; and third, (future) local staff members of international aid organisations. The 'Local Capacity Mobilising Initiative' in Bagan, ${ }^{20}$ for example, provides a self-study program that requires applied thinking and a high degree of discipline. The course has more than 10 modules, including socially relevant issues such as community organising and conflict management. Students basically work through the materials themselves but come together for regular group discussions. Starting from Bagan, the organisers have managed to extend the program to two other cities. In order to have a sustainable impact on local communities, the organisers are seeking ways to establish alumni groups of graduates, which they plan to link up with already existing community-based organisation and NGO welfare programs in different towns and villages. The certificates that students can acquire after completing NGO and community-based organisation capacity-building courses are not 
recognised by the government. At least one community-based organisation visited, however, had its certificates accredited by an international educational institution. Moreover, community-based organisation and NGO certificates are often recognised by the local and international aid organisations active in Burma/Myanmar for which community-based organisation and NGO capacity-building courses have come to serve as pools from which they recruit their staff.

\section{Community-based schools in rural areas}

In rural areas where there are no public schools, community-based schools (CBS) are often crucial as a means for providing village children with a primary education. Such CBS are established and organised in a variety of patterns. In cases where there is a public school building in the village, but the local government cannot pay for a teacher, local communities frequently establish informal groups and collect money to pay the village teacher themselves. If no professional teacher is prepared to work in the village, community-based organisations sometimes even choose a teacher from among themselves. Mostly, these makeshift teachers are community leaders who are respected people and who have a certain education as well as certain skills, but who have never been trained as teachers. If the next government school is too far away from the village - for example, in a neighbouring village or town - local community-based organisations sometimes even construct the school building on their own and then either share the teacher with a nearby government school or recruit and pay the teacher themselves. Officially, the government mostly declares CBS of this kind 'extensions' to the government schools nearest to them. In reality, however, the respective local communities themselves have made all the efforts and expenses to establish and run these schools. If the local government does not choose the strategy of cooption, but rather seeks to prevent the establishment of CBS, these schools often operate under religious umbrellas. In Christian communities, CBS are usually connected to the local church (see the Christian education section below), while in Buddhist communities they tend to take the form of Buddhist monasteries. ${ }^{21}$

CBS constitute a perfect example of how local civil-society groups try to bridge the accessibility gap that exists in the formal education system. The problem of the lack of educational quality usually persists, however, as the 'teachers' who volunteer at local CBS have often not been trained. Nevertheless, CBS also offer a wide range of advantages. As they are rooted in the local communities, they often provide work and life skills that are particularly needed in the respective locality, such as training in agricultural cultivation methods or basic veterinary skills. In some cases, such skills-training measures are even linked to income-generating activities. CBS also serve important communication purposes and can constitute forums in which environmental as well as health and 
preventive health issues - for example, in the field of HIV/AIDS - can be discussed. Often such health training is conducted by using various forms of traditional arts such as puppet shows (UNESCO 2002). The 'Community Learning Centre' project of the UN Development Program (UNDP) and the UN Educational, Scientific and Cultural Organisation (UNESCO), which started in 1994, has promoted CBS as centres for the provision of non-formal education. A report that summarised the experiences stressed that, due to poverty, insufficient enrolment and high drop-out rates, 'non-formal education will continue to be a necessity' in the future and models such as CBS will be needed 'to provide the population with complementary opportunities for basic education and life-long learning' (UNESCO 2002:30).

\section{Civil society-based education systems in cease-fire areas}

Because of the remoteness of many ethnic areas, the systematic neglect of the ethnic minorities by the central government and the legacy of armed conflict, the welfare system of the central state is particularly weak in Burma/Myanmar's ethnic minority regions. As for education in particular, the situation is often further aggravated by the regime's rigid and discriminatory language policies. For example, in several cases, the central government has established schools in ethnic areas but insisted that tuition be conducted in Burmese/Myanmar and it has hired teachers who do not even understand the local ethnic language. As a consequence, ethnic children who do not speak Burmese/Myanmar do not benefit, and some parents even refuse to send their children to school.

Since 1989, the regime has negotiated cease-fires with most of the armed ethnic resistance groups and granted them some degree of autonomy, which in some cases extends to language and education. As a consequence, various armed groups and their affiliated ethnic political parties, but particularly the Kachin Independence Organisation (KIO) and the New Mon State Party (NMSP), are running their own school systems. Even though these education systems often predate the cease-fires, they have extended considerably since the cease-fires. ${ }^{22}$ In Special Region 4 in Eastern Shan State, schools run by the central government exist alongside Chinese schools and so-called 'self-reliance schools', which operate under the authority of the education department of the National Democratic Alliance Army-Eastern Shan State (NDAA-ESS). The KIO, which has wide-ranging administrative autonomy over its area, is also allowed to have its own department for education and runs a teacher-training school (ICG 2003:9). The Kachin education system has about 1000 teachers. Most Kachin schools operate at the primary level, but there are also some Kachin middle and high schools. ${ }^{23}$ The NMSP also runs its own education department, which, since the 1995 cease-fire, has even managed to extend its programs to Mon communities in government-controlled areas (South 2007:164ff.). In 2003, the NMSP ran as many as 187 Mon national schools as well as 186 'mixed' schools - that is, schools 
shared with the public school system, in which minority languages are still banned (South 2007). Even the youngest of the cease-fire groups, the KNU/KNLA Peace Council (KPC), ${ }^{24}$ has already set up its own department of education. Although these para-statal administrative bodies and school systems do not constitute civil society-based education models as such, they are noteworthy because the line between the education system run by the central government and the alternative education systems provided by ethnic actors is gradually becoming blurred. This tendency is also evident among civil-society groups that have established alternative education programs in ethnic areas. Despite the highly ambivalent political character of most of the cease-fires, in some ethnic regions the resulting increase in ethnic autonomy has led to the emergence or enlargement of spaces for civil-society activities in the welfare sector in general and in the education sector in particular (Smith 1999; Purcell 1999; South 2004).

\section{Christian education}

Christian missionaries first introduced Christian education and church-run schools to Burma/Myanmar (for example, Zoellner 2007b). Even before British colonial times, a number of missionary schools were active in the country, and the first high school was in fact established by missionaries in 1872 (Tin 2004). After independence in 1948, the influence of the Christian schools was gradually pushed back as the $\mathrm{U} \mathrm{Nu}$ government started to establish a secular national education system as part of its project of nation building. As in many post-independence contexts, education was considered crucial for the construction of an independent national identity (see, for example, Zoellner 2007a). Nevertheless, various Christian denominations continued to run their own officially registered schools up to high-school level. After the military coup in 1962, however, these schools were either nationalised or closed down. The Christian churches have been prohibited from running officially recognised (primary and secondary) schools or registering any other formal education programs with the MOE ever since. Nevertheless, some big and well-established tertiary education institutions such as the Myanmar Institute of Theology (MIT) continue to run their programs up to the present day, even though they are recognised primarily not as educational but as religious institutions (see later in this section). Moreover, various community-based educational initiatives that are highly informal but are tolerated by the government still exist under the umbrella of the churches today, particularly in the ethnic cease-fire areas where the majority of the Christian population lives. In cease-fire areas and ethnic areas of continuing armed conflict, church-based education programs often go hand in hand with community-based initiatives such as the establishment of CBS, which is also taking place in government-controlled areas. As Daw May Oo (2004) puts it: 
There are several things the church organisations do. Certainly one is to address the social needs in society...for example, the schools in remote areas. Churches send teachers to volunteer in a community because the government does not have a system and any kind of infrastructure does not exist... Then communities will build the school on their own and the teachers most of the time will be provided by the churches, or even by the bible schools...So these fundamental needs like education...most of the time in remote areas, will be addressed by the church organisations, instead of the government having a program or a system.

Other church-based education support activities, for public and community-based schools alike, include the donation of schoolbooks and other teaching materials, teacher training and the provision of school-cost scholarships for poor children, which cover fees, books and uniforms. Some Christian churches also maintain hostels that are free of any charges. For many children from remote ethnic areas, this support is crucial, because poverty means they can afford to attend secondary school only if there is a free, church-run hostel in the town where the school is located. Most of the student hostels also offer homework supervision and extra-tuition programs, which are conducted either by staff members of local church organisations or by private volunteers for whose activities the local churches provide protective umbrellas.

Some Catholic dioceses use lay missionaries - 'zetamans' in the local language - in order to reach remote ethnic communities. Usually, it is the pastor who recruits the prospective zetamans from the young people in the diocese. Before sending them to the remote target areas, he trains them not only in bible studies but in basic secular educational and professional skills. After completing a preparation course, two zetamans at a time are sent to one remote community, where they are supposed to teach children basic literacy and numeracy skills, conduct training in agricultural methods as well as health education classes, and provide basic healthcare services for one year. The purpose of these teaching activities is, of course, not only welfare oriented, but to evangelise local communities (Geiger 2007).

Furthermore, according to a leading church official, the Christian churches run about 1500 pre-primary schools all over the country and in ethnic minority areas specifically. Interestingly, up to now, church-based pre-primary schools have been relatively free to formulate their own curriculum as long as they refrain from criticising the regime. Around 2006, however, the government announced it was going to develop national guidelines for the curricula of the church-based pre-primary schools. As jurisdiction over this matter seem to be divided (or even disputed) between the MOE and the MSW, however, this plan still seems to exist on paper only. Moreover, according to a church official, the government has announced that, in the future, teachers working at church-based pre-primary 
schools need to be trained by the government. The same church worker also said, however, that his/her organisation did not really worry about this plan, since the government had the capacity necessary to train only 50 pre-primary schoolteachers a year. Given the 1500 church-run pre-primary schools already in existence, this is totally insufficient.

Moreover, various Christian denominations run colleges-or so-called seminaries - that offer Christian education at a tertiary level and can be attended after matriculation. All in all, there seem to be about 30 seminaries across the country, but particularly in ethnic minority areas. Their prime ostensible mission is to teach bible studies, but as most of the books they use are in English, they also impart good spoken and written English skills. Many seminaries are highly self-organised and students often live in a compound. The 'Saint Markus Baptist College' in Lashio ${ }^{25}$ is one such example. In theory, all important decisions are supposed to be made by the principal. He/she, however, usually has to travel a lot and thus, in practice, a committee of teachers administers the college. Some of the younger teachers have international teaching experience and contacts with churches abroad. Moreover, there is a students' council, which organises community activities such as sports competitions. Asked whether and how the organisation was controlled by the government, a teacher said, 'They are watching us from a distance...We feel afraid. So this means, we are controlled.' The Myanmar Institute of Theology (MIT) in Yangon serves as a Christian university and issues bachelor and masters' degrees. Even though it provides tertiary education, it is registered as a religious and not an educational institution and operates under the MRA. Students at MIT can study not just theology, but a limited number of secular subjects including English and economics. The degrees that students can earn from the seminaries and from MIT are not recognised by the government. They are, however, mostly recognised within the national Christian community within which most of the students seek employment after completing their education.

In addition, several local churches as well as the Myanmar Council of Churches (MCC), a national umbrella association, have scholarship programs that enable gifted students and young church community leaders to attend university either in Burma/Myanmar or abroad. International partner churches provide financial support to some of these programs. Since in the past scholarship holders have often stayed abroad, some church organisations have now inserted clauses into their scholarship application guidelines that commit beneficiaries to return to Burma/Myanmar and work in their local communities for a certain period. Some scholarship programs have been quite successful. Recently, for example, a group of university graduates founded the 'Scholarship Alumni Association' in Myitkina, ${ }^{26}$ after returning from abroad. The association runs a church-based boarding school that targets local high-school graduates as well as the coordinators of the surrounding local churches' youth groups. Courses last for 
two years and focus on English, computer training and various professional skills including trade, management, accounting and agriculture. All boarding-school students are obligated to take part in 'social outreach activities' such as education and training programs aimed at the broader local community. Moreover, they have to pay visits to orphanages, hospitals and neighbouring villages. In order to promote creative thinking, the curriculum encompasses sports activities, teamwork, brainstorming, discussions and role-plays. The guidelines of the association also provide for a 'seniority system', which is specified as meaning that the older members - who are assumed to have more education and experience - must be respected and followed by their younger fellows.

Unlike the Sangha, Burma/Myanmar's Christian civil society often has rudimentarily institutionalised contacts with churches and even with international NGOs abroad. Such cooperation is, however, rarely coordinated and happens mostly on the basis of one church or NGO from abroad supporting one specific project or church within Burma/Myanmar. As a consequence, even international churches and organisations who have been working with churches in Burma/Myanmar for years usually do not have a coherent picture of the state of Christian civil society on the ground.

\section{NGO and community-based organisation education and education support activities}

Non-religious education and education support initiatives in ethnic cease-fire areas range from registered NGOs to highly informal community-based organisations. What all of them seem to have in common, however, is that in one way or another they are linked to the structures of the respective local ethnic cease-fire party.

The 'Alternative Local Learning Centre' in Kachin State, ${ }^{27}$ which started operating in 2005, provides a good example of a rather informal community-based organisation initiative in the education sector. It offers capacity building and informal training in the analysis of social problems, project management, proposal writing and accounting. The centre focuses on the training of trainers and its final goal is to promote the formation of new, self-reliant NGOs. (It started by training 20 participants in 2005.) Moreover, its founders have put enormous effort into the establishment of a library with literature on community development and other social issues. In order to reach an informal agreement with the local cease-fire party, the organisers had to prove that their project was apolitical and would provide capacities that were essential to economic development. According to one of the organisers, the centre is not registered but 'tolerated' by the local ethnic authorities. 
Other NGOs and community-based organisations have linked their education and education support activities even more closely to the local ethnic-party structures. The Metta Development Foundation, ${ }^{28}$ for example, has developed a strategic partnership with the Mon Women's Organisation and supported the latter's adult literacy and capacity-building programs (South 2007). One of the biggest Kachin NGOs provides planning support and child-centred teacher training to the KIO and its school system. Even in the Wa Special Region, where independent civil-society organisations are still rare, NGOs in partnership with local communities have established schools in areas in which schools have not existed before. In the Wa Special Region, such initiatives have often been supported by international NGOs as part of their drug-eradication programs. In most other ethnic areas, however, international support for ethnic NGO and community-based organisation activities often remains scarce and the lack of funding seems to pose the biggest obstacle to the further expansion of ethnic civil-society activities in the education sector. ${ }^{29}$

\section{Culture and literature committees}

Culture and Literature Committees (CLCs), which focus on the preservation and promotion of a specific ethnic language and culture, have a long tradition in Burma/Myanmar's ethnic minority areas. In the case of the Mon ethnic community, for example, South traces the emergence of cultural groups back to the 1930s and 1940s. The Mon Literature and Culture Committee (MLCC), which still exists today, started its ethnic literacy training in the 1950s (South 2007). In the same period, CLCs served as the backbone of ethnic nationalist movements in various ethnic states. Due to repression by the regime and civil war, ethnic activities in the fields of culture and literature were largely dormant from 1962 until the 1990s. Since the conclusion of cease-fires in the 1990s, however, the regime has allowed various ethnic parties to issue publications in their own ethnic tongues (ICG 2003). As a consequence, many traditional CLCs re-emerged and several new ones came into being. Moreover, in reaction to the failure of the state-run education system, many of them have started to go beyond their traditional task of cultural preservation. Today, most CLCs focus on basic literacy and teach children and illiterate adults important spoken and written language skills. Most CLCs teach the local ethnic language and rely on community education approaches such as informal education programs and summer schools. Some of them, however, already seem to have incorporated Burmese/Myanmar language and other non-culture-related subjects such as numeracy into their curriculum. According to a UN representative, some CLCs are even able to engage in formal education and have adopted the government curriculum, especially in Mon State. Most of these CLCs are active at the primary level; however, there also seem to be some that teach at a higher level and impart a number of skills. The role of the CLCs is particularly important in ethnic regions where children 
do not speak Burmese/Myanmar. Here, tuition in the local ethnic tongue might often constitute the only way children can acquire basic skills.

As CLCs are legal organisations that exist in almost every ethnic village, many different activities take place under their umbrella. For instance, some CLCs not only provide education, they conduct important community organisation and preventive health activities such as raising awareness about HIV/AIDS. For such specific purposes, CLCs seem to cooperate with other local and sometimes even international non-state actors. In Christian areas, for example, they sometimes cooperate with the local churches and in predominantly Buddhist regions they sometimes work with the Sangha. Mon monks, for instance, give language and literacy training courses at the MLCC (South 2007). According to a local staff member of an international aid organisation, his/her organisation sometimes relies on the local CLCs for the publication of its information materials on HIV/AIDS in remote ethnic areas. The head office of the aid organisation in Yangon usually publishes the information brochures in Burmese/Myanmar or English; subsequently, it is the local CLCs that translate them into the ethnic languages of the target regions, but they sometimes encounter problems when they seek censorship approval to publish such materials. On the whole, the international donor community does not seem to have a lot of contact with the CLCs, and detailed knowledge about their activities is still rather scarce. While CLCs impart highly valuable language skills and perform other important welfare functions, at least some of them tend to exclude members of other ethnic groups. Consequently, they also bear the risk of being culturally divisive, thereby reinforcing ethnic cleavages.

\section{Conclusion}

The picture of civil-society initiatives in the Burmese/Myanmar education sector is diverse and multifaceted. Nevertheless, it is possible to identify some general trends: first, there are quite a lot of community-based initiatives in the education sector in the broadest sense. Most of these community-based groups, however, cannot engage in education directly. Instead, they are confined to education support activities such as the construction of school buildings or the collection of donations to pay for village teachers' salaries. Second, there is a number-but definitely a small number - of civil-society groups that can engage in education more directly. Most of these apply informal, community-based approaches to teaching, whereas so far only a few groups have managed to become involved in formal education and been allowed to teach the government curriculum. Among the groups that are able to engage in formal education, monastic schools are undoubtedly the most prominent. Third, most educational initiatives that are aimed at children take place at the primary or even at the pre-primary level. While there are some at the middle-school level, only a handful exists at the high-school level. There are, however, also several educational initiatives for 
(young) adults in the sectors of vocational skills training and capacity building. Fourth, civil-society organisations active in the education sector often serve multiple social functions and, apart from education, many of them provide other welfare services as well. Education is often broadly understood to include (preventive) health education and general capacity building. Fifth, even though the number of civil-society initiatives in the education sector has been increasing during the past few years, the government is still extremely suspicious of all educational activities conducted by non-state actors. As a consequence, private education has not so far been legally provided for, and the majority of the civil-society groups that are active in the education sector cannot register with the MOE. As a makeshift solution, some of them have chosen to register with the MSW or the MRA.

This leads us to the last but perhaps the most important point: most civil society-based educational initiatives take place under religious or ethnic umbrellas, such as Buddhist monasteries, Christian churches and ethnic CLCs. This last point has broader implications: in present-day Burma/Myanmar, various secular, religious and ethnic (cultural) education systems - all of which promote different life models - coexist. In some cases, the boundaries between these various education and life models seem to be quite clear-cut. Some Buddhist monastic schools teach only the Dhamma, ${ }^{30}$ some Christian missionaries preach only the Gospels and some CLCs focus solely on the preservation of their ethnic cultural heritage; and, above all, there is a highly authoritarian state, which is still largely reluctant to accept the existence of an independent civil society and the alternative education systems it provides. There are, however, also cases where the boundaries between religious and ethnic (cultural) education on the one hand, and secular/non-cultural education on the other, are rather blurred. Traditional religious and ethnic cultural groups that predate the modern national education system have re-emerged and increasingly engage in secular, non-cultural and, in some rare cases, even formal education as well. New actors such as NGOs have also entered the scene. The rigidity of the regime's educational policies certainly does not reflect the reality on the ground. Instead of providing an enabling legal framework for private education, however, the regime still seeks mostly to either suppress or coopt alternative civil society-based education systems. Cooption of formerly independent groups thus constitutes another, negative form of the blurring of the lines between civil society-based and state-run education.

What does all this suggest in terms of the overall contribution that civil society is able to make to the education sector? While civil-society actors do provide valuable makeshift solutions to specific local problems, they lack the scope of action and the capabilities necessary to act as a substitute for a functioning state-run education system. The task of the latter would normally be to provide equal opportunities for quality education for the whole population regardless 
of status, religion or ethnicity. As civil-society actors in Burma/Myanmar usually provide localised, and sometimes even selective, services that are confined to specific religious and ethnic groups, they too are unable to live up to this task. Moreover, while civil-society actors manage to bridge some accessibility gaps in the state-run education system, they cannot bridge the quality gap. Instead, civil society-based education models tend to mirror the deficits of the state-run education system. The quality of education provided by civil-society groups varies widely and is sometimes highly inadequate. Just like professional teachers at government schools, voluntary teachers who teach at CBS or run free extra-tuition programs are often poorly trained and frequently rely on outdated teaching methods. As a consequence, tuition is often conducted in a highly hierarchical and repetitive way and learning remains mostly by rote. This is far from surprising, because the inadequate qualification of private and voluntary teachers results directly from the weakness of the state-run education system under which they received their own education and training.

The dynamics of civil-society development in Burma/Myanmar - in the education sector and in general-have not been well understood by the international community. The fact that hardly any expert or aid worker foresaw the 2007 uprising of the monks provides clear evidence for this. Extremely few international actors have contacts with the monastic schools, although they are the most important non-state providers of educational services. In fact, donor engagement with civil-society actors in the education sector has generally been limited up to now. An important reason for this is that Burma/Myanmar's embryonic civil society is only rarely able to live up to donor guidelines. Religious and ethnic education systems often promote philosophies and life models that donors are unfamiliar with. Cooption often gives civil society a double identity that makes donors feel uneasy. In order to develop better strategies, however, experts, politicians and aid workers will have to broaden their perspective to encompass the social dynamics of competing, parallel, coexisting and overlapping social systems in Burma/Myanmar. The case of civil-society development in the education sector is but one specific example that provides evidence for this blind spot.

\section{References}

Croissant, Aurel 2000, 'Zivilgesellschaft und transformation in Ostasien', in Wolfgang Merkel (ed.), Systemwechsel 5. Zivilgesellschaft und Transformation, Leske and Budrich, Opladen, pp. 335-72.

Department for International Development (DFID) 2008, Burma/Myanmar: UK assistance, Unpublished document, 17 April 2008, London.

Directory of Local Non-Government Organizations in Myanmar (DLN) 2005.

Edwards, Michael 2004, Civil Society, Polity Press, Cambridge. 
Englehart, Neil A. 2005, 'Is regime change enough for Burma? The problem of state capacity', Asian Survey, vol. 45, no. 4, July/August, pp. 622-44.

Foreign Policy Failed States Index 2007 2007, viewed 1 April 2008, $<$ http://www.foreignpolicy.com/story/cms.php?story_id=3865\&page=7>

Geiger, Heinrich (ed.) 2007, Myanmar. Bildung und Entwicklung in einem multiethnischen Staat, Köllen Druck and Verlag, KAAD, Bonn.

Gosewinkel, Dieter, Rucht, Dieter, van den Daele, Wolfgang and Kocka, Jürgen 2003, 'Introduction', in Dieter Gosewinkel, Dieter Rucht, Wolfgang van den Daele and Jürgen Kocka (eds), Zivilgesellschaft National und Transnational, Wissenschaftszentrum Berlin für Sozialforschung (WZB) Jahrbuch 2003, Edition Sigma, Berlin, pp. 11-26.

Heidel, Brian 2006, The Growth of Civil Society in Myanmar, viewed 25 April 2008, <http://him.civiblog.org/_attachments/1791034/Myanmarper cent20Civilper cent20Societyper cent20text.pdf $>$

Howell, Jude 1999, Manufacturing civil society from the outside: some dilemmas and challenges, Paper presented at the European Association of Development Research and Training Institutes Conference, September.

International Crisis Group (ICG) 2001, Myanmar: the role of civil society, ICG Asia Report No. 27, Bangkok/Brussels, viewed 10 March 2008, <http://www.crisisgroup.org/library/documents/report_archive/ A400503_06122001.pdf>

International Crisis Group (ICG) 2003, Myanmar backgrounder: ethnic minority politics, ICG Asia Report No. 52, Bangkok/Brussels, viewed 10 March 2008, <http://www.crisisgroup.org/library/documents/report_archive/ A400967_07052003.pdf>

Lauth, Hans-Joachim 2003, 'Zivilgesellschaft als Konzept und die Suche nach ihren Akteuren', in Arnd Bauerkämper (ed.), Die Praxis der Zivilgesellschaft. Akteure, Handeln und Strukturen im internationalen Vergleich, Campus Verlag, Frankfurt/New York, pp. 31-54.

London School of Economics (LSE) 2008, What is Civil Society?, viewed 28 February 2008, $<$ http://www.lse.ac.uk/collections/CCS/what_is_civil_society.htm>

Lorch, Jasmin 2006, 'Civil society under authoritarian rule: the case of Myanmar', SÜDOSTASIEN aktuell, issue 2/2006, pp. 3-37.

Lorch, Jasmin 2007, 'Myanmar's civil society - a patch for the national education system? The emergence of civil society in areas of state weakness', SÜDOSTASIEN aktuell, issue 3/2007, pp. 54-88. 
May Oo 2004, Director of Communication of the Free Burma Coalition, Interview, Washington D.C., 20 February.

Ministry of Education (MOE) 2006, EFA Implementation in Myanmar, Ministry of Education, Government of the Union of Myanmar.

Ministry of Education (MOE) 2007a, Education for All in Myanmar, Ministry of Education, Government of the Union of Myanmar.

Ministry of Education (MOE) 2007b, Towards Realizing the Millennium

Development Goals: Goal 2: Achieve universal primary education \& Goal

3: Promote gender equality and empower women, Ministry of Education, Government of the Union of Myanmar.

Ottaway, Marina 2004, 'Civil society', in Peter J. Burnell and Vicky Randall, Politics in the Developing World, Oxford University Press, Oxford, pp. 120-35.

Pedersen, Morten B., Rudland, Emily and May, Ronald J. (eds) 2000, Burma Myanmar. Strong regime weak state?, Crawford House Publishing, Adelaide.

Perinova, Marie 2005, Civil society in authoritarian regime. The analysis of China, Burma and Vietnam, Thesis, Department of Political Science, Lund University, viewed 30 September 2005, <http://theses.lub.lu.se/archive/2005/05/23/1116839547-15844-327/ thesis_of_Marie_Perinova.PDF>

Purcell, Marc 1999, 'Ace-handles or willing minions?: international NGOs in Burma', in Burma Center Netherlands and Transnational Institute (eds), Strengthening Civil Society in Burma. Possibilities and dilemmas for international NGOs, Silkworm Books, Chiang Mai, pp. 69-109.

Risse, Thomas 2005, 'Governance in Räumen begrenzter Staatlichkeit. “Failed states" werden zum zentralen Problem derWeltpolitik', Internationale Politik, September, pp. 6-12.

Rotberg, Robert I. 2002, 'The new nature of nation state failure', The Washington Quarterly, vol. 25, no. 3, pp. 85-96.

Rotberg, Robert I. 2004, 'Failed states, collapsed states, weak states: causes and indicators', in Robert I. Rotberg (ed.), When States Fail. Causes and consequences, Princeton University Press, Princeton, pp. 1-25.

Schneckener, Ulrich 2004, 'States at risk. Zur analyse fragiler Staatlichkeit', in Ulrich Schneckener (ed.), States at Risk. Fragile Staaten als Sicherheitsund Entwicklungsproblem, SWP Studie S 43, SWP, Berlin, pp. 5-27.

Schneckener, Ulrich 2006, 'States at risk. Zur analyse fragiler Staatlichkeit', in Ulrich Schneckener (ed.), 'States at Risk' zwischen Stabilität und Scheitern, 
SWP Internationale Politik und Sicherheit 59, Nomos, Baden-Baden, pp. 9-40.

Selth, Andrew 2001, Burma: a strategic perspective, Asia Foundation Working Paper No. 13, May 2001.

Smith, Martin 1999, 'Ethnic conflict and the challenge of civil society in Burma', in Burma Center Netherlands and Transnational Institute (eds), Strengthening Civil Society in Burma. Possibilities and dilemmas for international NGOs, Silkworm Books, Chiang Mai, pp. 15-53.

South, Ashley 2004, 'Political transition in Myanmar: a new model for democratization', Contemporary Southeast Asia. A Journal of International and Strategic Affairs, vol. 26, no. 2, pp. 233-55.

South, Ashley 2006, Email conversation, 16 November 2006.

South, Ashley 2007, 'Ceasefires and civil society: the case of the Mon', in Mikael Grawers (ed.), Exploring Ethnic Diversity in Burma, Nias Press, Copenhagen, pp. 149-77.

Steinberg, David I. 1999, 'A void in Myanmar: civil society in Burma', in Burma Center Netherlands and Transnational Institute (eds), Strengthening Civil Society in Burma. Possibilities and dilemmas for international NGOs, Silkworm Books, Chiang Mai, pp. 1-14.

Thawnghmung, Ardeth Maung and Myoe, Maung Aung 2008, 'Myanmar in 2007. A turning point in the "roadmap"?", Asian Survey, vol. 48, no. 1, pp. 13-19.

Tin, U Han 2004, Seminar on education in Myanmar, Paper presented at The Australian National University, 31 March 2004, Canberra, viewed 25 April 2008, <http://www.anu.edu.au/unesco/Tin.pdf>

United Nations Educational, Scientific and Cultural Organisation (UNESCO) 2002, Myanmar. The Community Learning Centre Experience, MYA/99/004, Improving Access of Children, Women and Men of Poorest Communities to Primary Education for All, UNESCO Asia and Pacific Regional Bureau for Education, Bangkok, viewed 25 April 2008, $<$ http://unesdoc.unesco.org/images/0012/001252/125290e.pdf>

United Nations International Children's Emergency Fund (UNICEF) 2008a, Providing Children With a Quality Basic Education, viewed 1 April 2008, <http://www.unicef.org/myanmar/education.html>

United Nations International Children's Emergency Fund (UNICEF) 2008b, UNICEF Program Helps Educate Children About HIV and AIDS, viewed 1 April 2008, <http://www.unicef.org/myanmar/education_1435.html> 
Will, Gerhard 2006, 'Birma: Stablie Herrschaft in einem versagenden Staat', in Ulrich Schneckener (ed.), 'States at Risk' zwischen Stabilität und Scheitern, SWP Internationale Politik und Sicherheit 59, Nomos, Baden-Baden, pp. 197-228.

Zoellner, Hans-Bernd 2007a, 'Zeitleiste. Daten zur Geschichte Mynamars/Birmas unter besonderer Berücksichtigung der Entwicklung des Bildungswesens', in Heinrich Geiger (ed.), Myanmar. Bildung und Entwicklung in einem multiethnischen Staat, KAAD, Köllen Druck and Verlag, Bonn, pp. 20-1.

Zoellner, Hans-Bernd 2007b, 'Erziehung und Bildung in Myanmar/Birma-Eine Collage', in Heinrich Geiger (ed.), Myanmar. Bildung und Entwicklung in einem multiethnischen Staat, KAAD, Köllen Druck and Verlag, Bonn, pp. 23-34.

\section{Endnotes}

1 This a modified and updated version of an earlier article on the same topic (Lorch 2007).

2 The '88 Generation Students Group comprises former student leaders of the 1988 uprising, who were released from jail in 2004. On 22 August 2007, several prominent '88 Group leaders were arrested again for their role in leading the demonstrations.

3 Community of Buddhist monks and nuns in Burma/Myanmar.

4 In 2001, an International Crisis Group (ICG 2001) report first referred to the existence of civil-society organisations in areas of welfare demands not met by the State, particularly in ethnic areas. Since the late 1990s, several experts have pointed to the enlargement of civil-society spaces in ethnic areas (for example, Purcell 1999:89ff.; Smith 1999:37-49; South 2004:233).

${ }^{5}$ UNICEF is active mainly in early childhood development, the establishment of child-friendly schools and education activities related to HIV/AIDS prevention (UNICEF 2008a, 2008b). Moreover, from 1994-2002, the Human Development Initiative (HDI) of the UN Development Program (UNDP) ran an education project in Burma/Myanmar. In 1994, a 'Community Learning Centre component' was introduced within the framework of this project. The Community Learning Centre subproject was funded by UNDP and conducted mainly by the UN Educational, Scientific and Cultural Organisation (UNESCO 2002: for a short description, see chapter 4.3).

6 Most of the information presented here was gathered in field trips between 2004 and early 2007. Several interviews were also conducted after September 2007 in order to assess the effects of the latest government crackdown on the civil-society initiatives reported.

7 For a good overview of normative conceptions of civil society, see Edwards (2004).

8 In my previous studies on civil society in Burma/Myanmar (Lorch 2006, 2007), which have a more theoretical focus, I have outlined a relational approach to civil society. For this purpose, I have linked the empirical descriptive definition of civil society of the London School of Economics (LSE 2008) cited here with the civil-society definition of Gosewinkel et al. (2003), who define civil society as specific types of action and interaction. As the present chapter focuses on the case rather than the theory, the LSE definition is chosen for the sake of brevity.

${ }^{9}$ Regarding the categorisation of Burma/Myanmar as a weak or failing state, see, for example, Englehart (2005); Foreign Policy Failed States Index (2007); Pedersen (2000); and Will (2006).

10 Confidential communication with Alan Smith, April 2008.

11 Ibid.

12 In the summer of 2006, several experts and monastic schoolteachers interviewed said that officially recognised monastic schools were registered with the MOE and that it was also the MOE to which all officially recognised monastic schools had to send their pupils' final exams for marking. During another research trip in 2007, officials from the MOE itself claimed that all monastic schools were under the 
MRA. Contrary to that, a publication of the MOE itself claims the MOE and the MRA are in charge of the officially recognised monastic schools (MOE 2006:25).

13 According to this second official source, there are 1158 officially recognised monastic schools, which altogether reach 161492 children. According to the same source, 144008 of these children are taught at the primary or post-primary level and only 17484 are taught at the middle level.

14 This information is based on various interviews conducted in Burma/Myanmar in the summer of 2006. While some of the people interviewed claimed that five monastic schools taught at the high-school level, others said there were only two. The author was able to visit one of them and read the funding proposal of a second one.

15 There seem to be almost no mixed monastic orphanages in Burma/Myanmar. Of the ones I visited, only one catered to both boys and girls.

16 The expert cited here specialises in Buddhism in Asia and is a lecturer at a European university, but has studied at a government university in Yangon for one year, still visits Burma/Myanmar frequently and maintains contacts with a number of monks and monastic education centres.

17 Confidential communication with Alan Smith, April 2008.

18 Organisation known to the author; name and place changed for safety reasons.

19 Confidential communication with Alan Smith, April 2008.

20 Organisation known to the author; name and place changed for safety reasons.

21 Confidential communication with Alan Smith, April 2008.

22 Email conversation with South, 16 November 2006. According to South, the Karen National Union (KNU), the best-known insurgent group, which is still fighting the central government, also runs its own education system, albeit on a smaller scale.

23 Confidential communication with Alan Smith, April 2008.

24 KNLA stands for Karen National Liberation Army; the KNLA is the armed wing of the KNU.

25 Organisation known to the author; name and place changed for safety reasons.

26 Organisation mentioned in Geiger (2007); name and place changed for safety reasons.

27 Organisation known to the author; name and place changed for safety reasons.

28 Established in 1998, Metta is the biggest registered independent NGO in Burma/Myanmar. It grew out of the Kachin cease-fire, but in recent years it has managed to extend its scope of action to other cease-fire areas as well.

29 Confidential communication with Alan Smith, April 2008.

30 Teachings of the Buddha. 